\title{
Penambahan Lower Extremity Strengthening Exercise Pada Core Stability Exercise Dalam Mengurangi Risiko Jatuh Pada Lansia
}

\author{
Yohana Melani ${ }^{1}$, Muthiah Munawwarah ${ }^{2}$, Jerry Maratis ${ }^{3}$ \\ ${ }^{1,2,3}$ Fakultas Fisioterapi Universitas Esa Unggul, Jakarta \\ Jl. Arjuna Utara No.9, RT.1/RW.2, Duri Kepa, Kec. Kb. Jeruk, Kota Jakarta Barat, Daerah \\ Khusus Ibukota Jakarta 11510 \\ Email: yohanamelani18@gmail.com
}

Tanggal Submisi: 20 April 2021; Tanggal Penerimaan: 21 Juni 2021

\begin{abstract}
ABSTRAK
Tujuan: Penelitian ini bertujuan untukmengetahui perbedaan penambahan lower extremity strengthening exercise pada core stability exercise dalam mengurangi risiko jatuh pada lansia.Metode: Penelitian ini bersifat quasi experiment dengan pre test-post test design group, dimana peningkatan keseimbangan diukur menggunakan Time Up and Go (TUG) test dan modified Sit to Stand (STS) test.Sampel dikelompokkan menjadi 2 kelompok, kelompok I terdiri dari 12 sampel dengan core stability exercise dan kelompok II terdiri dari 12 sampel dengan penambahan lower extremity strengthening exercise pada core stability exercise.Hasil: Uji normalitas dengan Shapiro Wilk test didapatkan data berdistribusi normal sedangkan uji homogenitas dengan Levene's test didapatkan data memiliki varian homogen. Hasil uji hipotesisI dan II dengan paired sample t-test didapatkan nilai $\mathrm{p}<0,001$ dan hasil uji hipotesis III dengan independent $t$-test menunjukan nilai $\mathrm{p}<0,001$ untuk TUG test dan $\mathrm{p}=0,007$ untuk modified STS test.Kesimpulan: Ada perbedaan yang signifikan penambahan lower extremity strengthening exercise pada core stability exercise dalam mengurangi risiko jatuh pada lansia Kata Kunci: Risiko jatuh pada lansia, lower extremity strengthening exercise, core stability exercise

\section{ABSTRACT}

Objective:To find out difference in the addition of lower extremity strengthening exercise interventions on core stability exercise can reduce the risk of falls in the elderly.Methods:This study was a quasi-experiment study with pre-test post-test group design, where improved balance was measured using Time Up and Go (TUG) tests and modified Sit to Stand (STS) tests.The samples were grouped into 2 groups, group I consisted of 12 samples with core stability exercise and group II consisted of 12 samples with the addition of lower extremity strengthening exercises on core stability exercise. Results:Normality test with Shapiro Wilk test obtained normal diffusion data while homogenity test with Levene's test gothomogenous data.The result of hypothesis test I and II with paired sample t-test was obtained $p<0,001$ and hypothesis III with independent t-test show the value $p<0,001$ for TUG test and $p=0,007$ for modified STS test. Conclusion: There are significant differences in the addition of lower extremity strengthening exercises on core stability exercise in reducing the risk of falls in the elderly.
\end{abstract}

Keywords:Risk of falling in elderly, lower extremity strengthening exercise, core stability exercis 


\section{PENDAHULUAN}

Menua bukan suatu hal yang bisa dihindarkan dan pasti akan dialami seluruh umat manusia apabila diberikan kesempatan untuk hidup lebih panjang. Lanjut usia atau disebut lansia bagi sebagian masyarakat tidak menghalanginya untuk tetap produktif, namun banyak juga lansia yang berjuang dengan permasalahan kesehatan ataupun kemandiriannya. Salah satu faktor yang sering dijumpai adalah risiko jatuh yang mengkhawatirkan lansia untuk beraktivitas sehingga populasi lansia dengan tingkat aktivitas fisik yang berkurang lebih memberikan risiko kesehatan yang menurun. Secara global populasi berusia 60 tahun atau lebih, tumbuh lebih cepat dari pada semua kelompok usia yang lebih muda (UN, 2017). Di Indonesia Umur Harapan Hidup (UHH) atau Angka Harapan Hidup (AHH) berdasarkan laporan Badan Pusat Statistik (BPS) terjadi peningkatan UHH pada tahun 2011 menjadi 69,65 tahun (dengan persentase populasi lansia adalah $7,58 \%$ ), tahun 2017 diperkirakan terdapat 23,66 juta jiwa penduduk lansia di Indonesia (9,03\%) berdasarkan data proyeksi penduduk. Dalam memasuki usia lanjut gangguan keseimbangan berkaitan dengan sitem visual, vestibular, proprioception, kekuatan otot dan waktu reaksi menjadi kendala pada lansia, karena bertambahnya usia akan diikuti dengan penurunan fungsi-fungsi sistem secara progresif yang dapat berkontribusi pada penurunan keseimbangan.

Keseimbangan atau balance adalah tugas kontrol motorik kompleks yang melibatkan deteksi dan integrasi informasi sensorik untuk memeriksa posisi dan gerakan tubuh dan melakukan respon muskuloskeletal yang sesuai di dalam konteks lingkungan dan tugas, karena itu kontrol keseimbangan membutuhkan interaksi sistem saraf dan muskuloskeletal serta efek kontekstual. Sistem saraf berperan dalam pengolahan sensorik untuk persepsi orientasi ruang tubuh yang paling banyak dilakukan oleh sistem somatosensorik/ proprioceptive, sistem vestibular dan sistem visual. Sistem somatosensorik memberikan mengenai posisi dan gerakan tubuh serta bagian tubuh terhadap satu sama lain dan terhadap permukaan penyangga. Proprioseptor otot, mencakup muscle spindles dan golgi tendon organ (sensitif terhadap panjang dan tekanan otot), joint receptor (sensitif terhadap posisi, gerak, dan tekanan sendi) dan mekanoresptor kulit (sensasi getaran, sentuhan ringan, tekanan dalam dan peregangan kulit) adalah masukan sensorik dominan untuk mempertahankan keseimbangan ketika permukaan penyangganya keras, datar dan terfiksasi. Sistem visual memberikan informasi posisi kepala terhadap lingkungan, orientasi kepala untuk mempertahankan level pandangan serta arah dan kecepatan gerak kepala. Sistem vestibular memberikan informasi mengenai posisi dan gerakan kepala terhadap gravitasi. Berkurangnya somatosensasi pada ektremitas bawah disebabkan oleh polineuropati perifer pada lansia. Defisit dalam komponen motorik kontrol menyebabkan penurunan performa otot seperti postur yang buruk, keterbatasan lingkup gerak sendi yang mempengaruhi keseimbangan (Kisner and Colby, 2013).

Dalam memelihara gerak dan fungsi, fisioterapis dapat berperan dalam promosi dan preventif pencegahan jatuh pada lansia. Sesuai dengan peran fisioterapi menurut Permenkes RI No. 65 Pasal 1 ayat 2 tentang standar pelayanan fisioterapi yaitu: "Fisioterapi adalah bentuk pelayanan kesehatan yang ditujukan kepada individu dan atau kelompok untuk mengembangkan, memelihara dan memulihkan gerak dan fungsi tubuh sepanjang daur kehidupan dengan menggunakan penanganan secara manual, peningkatan gerak, peralatan (fisik, elektroterapeutis dan mekanis) pelatihan fungsi dan komunikasi".

Upaya yang bisa dilakukan fisioterapi dalam meningkatkan pencegahan risiko jatuh pada lansia tersebut adalah dengan penerapan intervensi core stability exercise dan lower extremity strengthening exercise yang diprogramkan dengan baik, mudah dilakukan dan tidak memerlukan peralatan yang mahal 
menyebabkan tidak hanya pada kekuatan otot yang meningkat tetapi juga untuk memperbaiki keseimbangan pada lansia. Core stability exercise digunakan untuk memperkuat otot-otot di sekitar perut, pinggang dan daerah panggul karena otot-otot daerah ini memainkan peran penting dalam stabilitas serta dalam mengendalikan postur dengan menggunakan otot tonik atau postural selama latihan seluruh tubuh. Tujuannya untuk meningkatkan kontrol neuromuskuler, daya tahan, kekuatan otot core dalam mempertahankan stabilitas tulang belakang yang dinamis. Otot transversus abdominis, otot lumbar multifidi, otot paraspinal, diafragma, dan otot-otot panggul lainnya ditargetkan dalam ini. (Akhtar et al, 2017).

Latihan kekuatan adalah setiap aktivitas yang membuat otot bekerja lebih keras dari biasanya. Tujuan latihan ini meningkatkan kekuatan, ukuran, tenaga dan daya tahan otot tubuh. Latihannya dapat menggunakan berat badan atau melawan resistensi. Lower extremity strengthening exercise dapat meningkatkan kekuatan kaki, keseimbangan dan koordinasi yang membantu mempertahankan dan meningkatkan kekuatan otot dan menghindari jatuh saat bertambah tua (Cho et al, 2014).

Latihanini bermanfaat untuk memperkuat otot dalam rangka membantu mempertahankan kemampuan untuk melakukan tugas sehari-hari dan memperlambat pengeroposan tulang dan kehilangan otot yang terkait dengan penuaan. Latihan semacam itu juga dapat membantu mengurangi peluang untuk jatuh (Hewitt et al, 2014).

Pencegahan jatuh pada lansia dengan program latihan otot core dan lower extremity strengthening exercise guna mempertahankan keseimbangan sudah terbukti memberikan manfaat yang positif (Reid et al, 2008). Core stability exercise akan berpengaruh pada pengembangan kerja otot dynamic muscular corset (Kisner and Colby, 2013), peningkatan kekuatan otot lower exteremity memberikan kemampuan untuk menopang tubuh yang lebih baik dalam tugas fungsionalnya sehingga faktor penurunan massa otot atau sarcopenia pada lansia dapat diperlambat prosesnya.

\section{METODE PENELITIAN}

Sampel sebanyak 24 orang yang dipilih melalui assesmen fisioterapi dan kriteria yang telah ditentukan yakni lansia dengan gangguan keseimbangan berusia 60-80 tahun, memiliki nilai TUG sama dengan atau lebih dari 14 dannilai modified STS kurang dari 12. Pemilihan sampel dilakukan secara ramdomized allocation dan dibagi kedalam 2 kelompok dengan masingmasing kelompok berjumlah 12 orang, dimana kelompok perlakuan I diberikan intervensi core stability exercise, sedangkan kelompok perlakuan II diberikan intervensi core stability exercise danlower extremity strengthening exercise.Sebelum diberikan perlakuan, peneliti melakukan pengukuran keseimbangan lansia dengan TUG tes dan modified STS. Selanjutnya sampel diberikan perlakuan sebanyak 24 kali selama 6 minggu.

\section{HASIL PENELITIAN}

\section{Pengukuran TUG test dan Modified STS Sebelum dan Sesudah Intervensi}

Pada penelitian ini, TUG test dan modified STS digunakan sebagai alat ukur yang berfungsi untuk mengukur keseimbangan lansia pada kelompok perlakuan I dan II. Berikut ini adalah hasil pengukuran TUG testdan modifedSTS pada kelompok perlakuan I dan kelompok perlakuan II. 
Tabel 1

Hasil Pengukuran TUG test Pada Kelompok Perlakuan I dan Kelompok Perlakuan II

\begin{tabular}{ccccccc}
\hline & \multicolumn{3}{c}{ Kelompok Perlakuan I } & \multicolumn{3}{c}{ Kelompok Perlakuan II } \\
\cline { 2 - 7 } Sampel & $\begin{array}{c}\text { TUG } \\
\text { pre }\end{array}$ & $\begin{array}{c}\text { TUG } \\
\text { post }\end{array}$ & Selisih & $\begin{array}{c}\text { TUG } \\
\text { pre }\end{array}$ & $\begin{array}{c}\text { TUG } \\
\text { post }\end{array}$ & Selisih \\
\hline 1 & 15.31 & 13.82 & 1.49 & 15.05 & 10.55 & 4.5 \\
2 & 15.52 & 14.76 & 0.76 & 14.8 & 10.41 & 4.39 \\
3 & 15.26 & 14.24 & 1.02 & 16.09 & 11.54 & 4.55 \\
4 & 14.29 & 12.18 & 2.11 & 15.27 & 10.34 & 4.93 \\
5 & 15.49 & 13.78 & 1.71 & 15.18 & 11.5 & 3.68 \\
6 & 16.32 & 14.2 & 2.12 & 14.87 & 10.21 & 4.66 \\
7 & 15.23 & 13.85 & 1.38 & 14.25 & 10.92 & 3.33 \\
8 & 14.37 & 12.95 & 1.42 & 15.33 & 10.26 & 5.07 \\
9 & 15.42 & 15.07 & 0.35 & 14.12 & 9.88 & 4.24 \\
10 & 14.67 & 13.46 & 1.21 & 16.74 & 11.59 & 5.15 \\
11 & 14.22 & 12.86 & 1.36 & 14.38 & 10.43 & 3.95 \\
12 & 16.09 & 13.99 & 2.1 & 15.16 & 10.58 & 4.58 \\
\hline Mean & 15.18 & 13.76 & 1.42 & 15.10 & 10.68 & 4.42 \\
SD & 0.68 & 0.81 & 0.55 & 0.75 & 0.57 & 0.55 \\
\hline
\end{tabular}

Pada tabel 1 di atas menunjukkan hasil dari pengukuran TUGtest pada kelompok perlakuan I sebelum diberikan latihan menghasilkan nilai $15,18 \pm 0,68$. Sedangkan pada pengukuran TUGtest sesudah diberikan core stability exercise menghasilkan nilai $13,76 \pm 0,81$. Perhitungan selisih nilai pengukuran TUG test sebelum dan sesudah diberikan core stability exercise, menghasilkan nilai 1,42 $\pm 0,55$.

Pada nilai kelompok perlakuan II dengan pengukuran TUG test sebelum diberikan penambahan lower extremity strengthening dan core stability exercise menghasilkan nilai $15,10 \pm 0,75$. Sedangkan pada pengukuran TUG test sesudah diberikan penambahan lower extremity strengthening dan core stability exercise menghasilkan nilai $10,68 \pm 0,57$. Jika dilakukan perhitungan selisih nilai pengukuran TUG testsebelum dan sesudah diberikan penambahan lower extremity strengthening dan core stability exercise, menghasilkan nilai $4,42 \pm 0,55$. 
Tabel 2 Hasil Pengukuran Modified STS Pada Kelompok Perlakuan I dan Kelompok Perlakuan II

\begin{tabular}{ccccccc}
\hline & \multicolumn{3}{c}{ Kelompok Perlakuan I } & \multicolumn{3}{c}{ Kelompok Perlakuan II } \\
\cline { 2 - 7 } Sampel & STS & STS & & STS & STS & \\
& pre & post & Selisih & pre & post & Selisih \\
\hline 1 & 8 & 12 & 4 & 9 & 18 & 9 \\
2 & 11 & 16 & 5 & 8 & 15 & 7 \\
3 & 8 & 12 & 4 & 9 & 16 & 7 \\
4 & 10 & 16 & 6 & 8 & 15 & 7 \\
5 & 10 & 15 & 5 & 8 & 14 & 6 \\
6 & 8 & 13 & 5 & 9 & 19 & 10 \\
7 & 10 & 15 & 5 & 8 & 17 & 9 \\
8 & 9 & 13 & 4 & 7 & 13 & 6 \\
9 & 8 & 14 & 6 & 10 & 18 & 8 \\
10 & 9 & 15 & 6 & 7 & 12 & 5 \\
11 & 12 & 19 & 7 & 8 & 13 & 5 \\
12 & 7 & 12 & 5 & 8 & 12 & 4 \\
\hline Mean & 9.17 & 14.33 & 5.17 & 8.25 & 15.17 & 6.92 \\
SD & 1.47 & 2.10 & 0.94 & 0.87 & 2.44 & 1.83 \\
\hline
\end{tabular}

Pada tabel 2 terlihat hasil dari pengukuran modified STS test pada kelompok perlakuan I sebelum diberikan latihan menghasilkan nilai $9,17 \pm 1,47$. Sedangkan pada pengukuran modified STS test sesudah diberikan latihan menghasilkan nilai 14,33 $\pm 2,10$. Hasil perhitungan selisih nilai pengukuran modified STS test sebelum dan sesudah diberikan lower extremity strengthening dan core stability

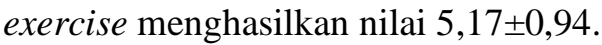

Pada nilai kelompok perlakuan II dengan pengukuran modified STS test sebelum diberikan latihan menghasilkan nilai 8,25 $\pm 0,87$. Sedangkan pada pengukuran modified STS test sesudah diberikan latihan menghasilkan nilai $15,17 \pm 2,44$. Hasil perhitungan selisih nilai pengukuran modified STS test sebelum dan sesudah diberikan lower extremity strengthening dan core stability exercise, menghasilkan nilai $6,92 \pm 1,83$.

\section{Uji Normalitas}

Setelah dilakukan uji Shapiro Wilk Test didapatkan kesimpulan bahwa sampel terditribusi secara normal.

\section{Uji Homogenitas}

Setelah dilakukan uji homogenitas (Levene' test) didapatkan

kesimpulan bahwa varian data homogen. 
Tabel 3 Hasil Uji Normalitas Time Up and Go (TUG test)

\begin{tabular}{lcc}
\hline \multicolumn{1}{c}{ Perlakuan } & p value* & Keterangan \\
\hline Perlakuan I sebelum & 0,377 & Normal \\
Perlakuan I sesudah & 0,920 & Normal \\
Perlakuan I selisih & 0,508 & Normal \\
Perlakuan II sebelum & 0,321 & Normal \\
Perlakuan II sesudah & 0,082 & Normal \\
Perlakuan II selisih & 0,645 & Normal \\
\hline
\end{tabular}

* Saphiro Wilk test

Tabel 4

Hasil Uji Normalitas Modified Sit To Stand (STS test)

\begin{tabular}{lcc}
\hline \multicolumn{1}{c}{ Perlakuan } & p value* & Keterangan \\
\hline Perlakuan I sebelum & 0,448 & Normal \\
Perlakuan I sesudah & 0,179 & Normal \\
Perlakuan I selisih & 0,123 & Normal \\
Perlakuan II sebelum & 0,099 & Normal \\
Perlakuan II sesudah & 0,395 & Normal \\
Perlakuan II selisih & 0,829 & Normal
\end{tabular}

* Saphiro Wilk test

Tabel 5

Hasil Uji Homogenitas Time Up and Go (TUG test)

\begin{tabular}{lcc}
\hline \multicolumn{1}{c}{ Perlakuan } & p value* & Keterangan \\
\hline Kelompok Sebelum Perlakuan I dan II & 0,979 & Homogen \\
\hline Levene's test & &
\end{tabular}

Tabel 6

Hasil Uji HomogenitasModified Sit To Stand (STS test)

\begin{tabular}{ccc}
\hline Perlakuan & p value* & Keterangan \\
\hline Kelompok Sebelum Perlakuan I dan II & 0,061 & Homogen \\
\hline
\end{tabular}

*Levene's tes

Dari kedua hasil pengujian diatas (uji normalitas dan uji homogenitas) maka ditetapkan:

\section{Uji Hipotesis I dan Hipotesis II}

Untuk menguji signifikasi dua sampel yang saling berpasangan pada kelompok I dan a. Pengujian hipotesis I dan II menggunakan uji parametrikyaitu paired sample t-test

b. Pengujian hipotesis III menggunakan uji parametrikyaitu independent sample t-test.

kelompok II, dengandata terdistribusi normal maka digunakan paired sample t-test. 
Tabel 7 Nilai Uji Hipotesis I Untuk TUG test dan Modified STS test

\begin{tabular}{|c|c|c|c|c|c|}
\hline \multicolumn{3}{|c|}{ Uji Hipotesis I TUG test } & \multicolumn{3}{|c|}{ Uji Hipotesis I Modified STS test } \\
\hline Variabel & Mean \pm SD & $\mathrm{p}$ value ${ }^{*}$ & Variabel & Mean \pm SD & p value* \\
\hline Sebelum & $15,18 \pm 0,68$ & $\mathrm{p}<0,001$ & Sebelum & $9,17 \pm 1,47$ & $\mathrm{p}<0.001$ \\
\hline
\end{tabular}

*paired sample t-test

Tabel 8

Nilai Uji Hipotesis II Untuk TUG test dan Modified STS test

\begin{tabular}{cccccc}
\hline \multicolumn{2}{l}{ Uji Hipotesis II TUG test } & & \multicolumn{2}{c}{ Uji Hipotesis II Modified STS test } \\
\hline Variabel & Mean \pm SD & p value $^{*}$ & Variabel & Mean \pm SD & p value \\
\hline Sebelum & $15,10 \pm 0,75$ & \multirow{2}{*}{$<0.001$} & Sebelum & $8,25 \pm 0,87$ & p $<0.001$ \\
Sesudah & $10,68 \pm 0,57$ & & Sesudah & $15,17 \pm, 44$ & \\
\hline
\end{tabular}

*paired sample t-test

Berdasarkan tabel di atas, pada pengujian hipotesis I dapat disimpulkan bahwa intervensi core stability exercise dapat mengurangi risiko jatuh pada lansia sedangkan untuk pengujian

\section{Uji Hipotesis III}

Untuk menguji signifikannya dua sampel yang saling berpasangan pada kelompok perlakuan I dan kelompok perlakuan II, dengan hipotesis II dapat disimpulkan penambahan intervensi lower extremity strengthening exercisepada core stability exercise dapat mengurangi risiko jatuh pada lansia.

Tabel 9

Nilai Uji Hipotesis III Untuk TUG test dan Modified STS test

\begin{tabular}{|c|c|c|c|c|}
\hline \multirow{2}{*}{ Variabel } & \multirow{2}{*}{$\begin{array}{c}\text { TUG test } \\
(\text { Mean } \pm \mathrm{SD})\end{array}$} & \multirow{2}{*}{$\begin{array}{c}\text { Modified STS test } \\
(\text { Mean } \pm \text { SD })\end{array}$} & \multicolumn{2}{|c|}{$\mathrm{p}$ value ${ }^{*}$} \\
\hline & & & TUG test & Modified STS test \\
\hline \multirow{2}{*}{$\begin{array}{l}\text { Selisih I } \\
\text { Selisih II }\end{array}$} & $1,42 \pm 0,55$ & $5,17 \pm 0,94$ & \multirow{2}{*}{$\mathrm{p}<0,001$} & \multirow{2}{*}{0,007} \\
\hline & $4,42 \pm 0,55$ & $6,92 \pm 1,83$ & & \\
\hline
\end{tabular}

*Independent sample t- test

\section{PEMBAHASAN}

1. Efek core stability exercise dalam mengurangi risiko jatuh pada lansia

Pada penelitian ini kelompok perlakuan I terdiri dari 12 orang sampel dan diberikan core stability exercise. Untuk mengetahui adanya peningkatan keseimbangan pada lansia diukur menggunakan TUG test dan modified STS test. Berdasarkan tabel 1 dan 2 diketahui pengukuran keseimbangan dengan TUG test sebelum diberikan intervensi adalah $15,18 \pm 0,68$ dan sesudah intervensi $13,76 \pm 0,81$. Perhitungan selisih nilai pengukuran TUG test sebelum dan sesudah diberikan core stability exercise, menghasilkan nilai 1,42 $\pm 0,55$. Sedangkan pengukuran dengan menggunakan modified STS test sebelum diberikan intervensi adalah $9,17 \pm 1,47$ dan sesudah diberikan latihan menghasilkan nilai $14,33 \pm 2,10$. Hasil perhitungan selisih nilai pengukuran modified STS test sebelum dan sesudah diberikan lower extremity strengthening dan core stability exercise


dilakukan paired sample t-test didapatkan nilai $\mathrm{p}<0,001$ yang berarti bahwa core stability exercise 
dapat meningkatkan keseimbangan sehingga mengurangi risiko jatuh pada lansia.

Hal tersebut terjadi karena otot core yang kuat akan membantu menstabilkan tulang belakang, panggul dan kinetic chain selama gerakan fungsional. Tanpa kerja otot core, tulang belakang akan menjadi tidak stabil secara mekanis. Sistem stabilitas tulang belakang terdiri dari elemen yang berinteraksi yaitu kontrol neuromuskular, subsistem pasif (tulang dan ligamen) dan subsistem aktif (otot). Dengan kata lain, stabilitas tulang belakang tidak hanya bergantung pada kekuatan otot, tetapi juga masukan sensorik yang tepat yang memberi tahu sistem saraf pusat tentang interaksi antara tubuh dan lingkungan, memberikan umpan balik yang konstan dan memungkinkan penyempurnaan gerakan (Akuthota et al, 2008). Dengan kembali aktifnya otot core, kerja proprioseptif akan terjaga sehingga kontrol keseimbangan dan postural normal akan tercapai pada lansia. Untuk hal tersebut program core stability exercise akan mempertimbangkan komponen sensorik dan motorik yang terkait dengan sistem ini yang tujuannya stabilisasi tulang belakang optimal tercapai sehingga lansia dapat mengontrol tubuhnya terhadap lingkungan sekitar dan risiko jatuh dapat diperkecil. Berdasarkan penelitian Ko et al (2014) yang berjudul "Analysis of Core Stability Exercise Effect on the Physical and Psychological Function of Elderly Women Vulnerable to Falls during Obstacle Negotiation", core stability exercise dapat meningkatkan kemampuan kontrol keseimbangan dengan memperkuat otot intersegmental di multifidus, transversus abdominis, dan rotator yang bekerja secara harmonis dengan merangsang proprioseptif. Core stability exercise difokuskan untuk mengatasi stabilitas antar-segmen dengan memfasilitasi kontrol neuromuskular di tulang belakang lumbar.

2. Efek penambahan lower extremitystrengthening exercise pada core stability exercise dalam mengurangi risiko jatuh pada lansia
Pada penelitian ini kelompok perlakuan II terdiri dari 12 orang sampel dan diberikan penambahan lower extremity strengthening exercise dan core stability exercise. Untuk mengetahui adanya peningkatan keseimbangan pada lansia diukur menggunakan TUG test dan modified STS test. Berdasarkan tabel 1 dan 2 diketahui pengukuran keseimbangan dengan TUG test sebelum diberikan intervensi adalah15,10 $\pm 0,75$ dan sesudah intervensi10,68 $\pm 0,57$.Perhitungan selisih nilai pengukuran TUG test sebelum dan sesudah diberikan penambahan lower extremity strengthening dan core stability exercise, menghasilkan nilai 4,42 $\pm 0,55$.Sedangkan pengukuran modified STS test sebelum diberikan latihan menghasilkan nilai $8,25 \pm 0,87$ dan sesudah

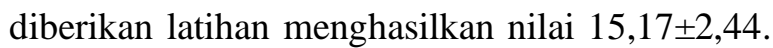
Hasil perhitungan selisih nilai pengukuran modified STS test sebelum dan sesudah diberikan lower extremity strengthening dan core stability exercise, menghasilkan nilai $6,92 \pm 1,83$.Kemudian dilakukan paired sample t-test didapatkan nilai $\mathrm{p}<0,001$ yang berarti bahwa penambahan lower extremity strengthening exercise padacore stability exercise dapat meningkatkan keseimbangan lansia sehingga mengurangi risiko jatuh pada lansia.

Hal tersebut terjadi karena lower extremity strengthening exercisedapat meningkatkan keseimbangan pada lansia dengan mempertahankan kekuatan otot dan menjaga fungsionalnya secara keseluruhan anggota gerak bawah sebagai penopang tubuh yang dalam jangka panjang meningkatan kontrol postural (Mayer et al, 2011). Otak mengoordinasikan impuls dari mata, telinga bagian dalam dan proprioception mengirimkan sinyal tersebut ke sistem otot untuk bergerak atau melakukan penyesuaian untuk menjaga keseimbangan. Reaksi dan kemampuan otot dalam melakukan fungsinya akan memampukan body awareness lansia mempertahankan keseimbangannya sehingga risiko jatuh lebih diperkecil. Hasil ini menguatkan penelitian sebelumnya oleh Lee dan Park (2013) yang berjudul "Balance Improvement by Strength 
Training for the Elderly", menyimpulkan bahwa latihan penguatan yang diprogramkan dengan baik tidak hanya untuk meningkatkan kekuatan tetapi juga untuk meningkatkan keseimbangan statis pada lansia.

\section{Ada Perbedaan Penambahan Lower Extremity Strengthening Exercise pada Core Stability Exercise dalam Mengurangi Risiko Jatuh pada Lansia}

Serangkaian uji hipotesis pada kedua kelompok dilakukan untuk membuktikan bahwa adanya perbedaan penambahan lower extremity strengthening exercise pada core stability exercise dalam mengurangi risiko jatuh pada lansia. Dilihat dari nilai selisih TUG test kelompok perlakuan I adalah $1,42 \pm 0,55$ dan perlakuan II $4,42 \pm 0,55$. Pada modified STS test nilai selisih kelompok perlakuan I 5,17 $\pm 0,94$ dan kelompok perlakuan II $6,92 \pm 1,83$, menunjukkan hasil peningkatan keseimbangan pada kelompok perlakuan II yang signifikan. Kemudian dilakukan uji parametrik yaitu independent sample t-test didapatkan nilai $\mathrm{p}<0,001$ untuk peningkatan keseimbangan dengan TUG test dan nilai $\mathrm{p}=0,007$ untuk peningkatan keseimbangan dengan modified STS test yang berarti ada perbedaan penambahan lower extremity strengthening exercise pada core stability exercise.

Jika dilihat melalui tren dari hasil pengukuran keseimbangan pada kelompok perlakuan II dimana tren yang lebih besar terlihat pada pengukuran TUG test dan modified STS sebelum dan sesudah pemberian intervensi minggu ke VI. Penambahan lower extremity strengthening exercise pada core stability exercisedapat memberikan hasil yang baik dalam peningkatan keseimbangan pada lansia karena pada core stability exercise akan membantu mempertahankan fleksibilitas dan stabilitas otot core serta koreksi postur pada lansia. Ketika otototot core berfungsi normal, stabilitas segmental tulang belakang dapat dipertahankan sehingga mengurangi stres pada vertebra lumbal dan diskus intervertebralis akibatnya lansia dapat mengontrol postur tubuh dengan baik dan keseimbangannya terhadap medan gravitasi dapat dipertahankan hasilnya risiko akan terjatuh semakin kecil.

$\begin{array}{ccc}\text { Sedangkan } & \text { penambahan } & \text { lower } \\ \text { extremitystrengthening } & \text { exercise } & \text { dapat } \\ \text { memperkuat jaringan } & \text { lunak }\end{array}$

memperkuat jaringan lunak yang akan berpengaruh terhadap ukuran, kekuatan dan kapasitas otot sehingga akan mengurangi efek perubahan sistem muskuloskeletal akibat penuaan serta terjadinya perbaikan proprioceptif.Melalui latihan ini juga akan mempertahankan kekuatan otot pada lansia yang mengalami penurunan dan menjaga fungsional anggota gerak bawah sebagai penopang tubuh yang dalam jangka panjang juga dapatmeningkatkan kontrol posturalsehinggamengurangi risiko jatuh pada lansia terutama dalam melakukan aktivitas seharihari.

\section{KESIMPULAN}

Berdasarkan hasil penelitian dan pembahasan pada bab sebelumnya maka dapat diambil kesimpulan sebagai berikut:

1. Intervensi core stability exercise dapat mengurangi risiko jatuh pada lansia.

2. Penambahan lower extremity strengthening exercise pada core stability exercise dapat mengurangi risiko jatuh pada lansia.

3. Ada perbedaan penambahan lower extremity strengthening exercise pada core stability exercise dalam mengurangi risiko jatuh pada lansia.

\section{REFERENSI}

Akhtar, Muhammad Waseem., Hossein Karimi and Syed Amir Gilani. 2017. Effectiveness of Core Stabilization Exercises and Routine Exercise Therapy in Management of Pain in Chronic Non-Specific Low Back Pain: A Randomized Controlled Clinical Trial. Pakistan Journal of Medical Science. 33(4):1002-1006.

Akuthota, et al. 2008. Core Stability Exercise Principles. Current Sports Medicine Reports. 7(1):39-44. 
Cho Seong-Il and Duk-Hyun. 2014. An Effects of a Fall Prevention Exercise Program on Muscle Strength and Balance of the Old-old Elderly. Journal of Physical Therapy Science. 26(11): 1771-1774.

Hewitt Jennifer, Kathryn M Refshauge, Stephen Goodall, Timothy Henwood, Lindy Clemson. 2014. Does Progressive Resistance and Balance Exercise Reduce Falls in Residential Aged Care? Randomized Controlled Trial Protocol for the SUNBEAM Program. Journal of Clinical Intervention in Aging. 9: 369-376.

Joshua, et al. 2009. Effectiveness of Progressive Resistance Strength Training versus Traditional Balance Exercise in Improving Balance among the Elderly-a Randomised Controlled Trial. Journal of Clinical and Diagnostic Reseacher. 8(3): 98-102.

Kemenkes RI. 2015. Standar Pelayanan Fisioterapi. PMK No. 65 Tahun 2015Kemenkes. Jakarta.
Kisner, Carolyn and Colby Lynn A. 2013. Theraupetic Exercise Fuundation and Techniques Six Edition. Philadelphia : F.A. Davis Company.

Ko Dae-Sik, Dae-In Jung and Mi-Ae Jeong. 2014. Analysis of Core Stability Exercise Effect on the Physical and Psychological Function of Elderly Women Vulnerable to Falls during Obstacle Negotiation. Journal of Physical Therapy Science. 26(11): 1697-1700.

Mayer, Frank et al.2011. The Intensity and Effects of Strength Training in the Elderly. Deutsches Arzteblatt International. 108(21): 359-364.

Lee In-Hee dan Park Sang-Young. 2013. Balance Improvement by Strength Training for the Elderly. Journal of Physical Therapy Science. 25(12): 1591-1593.

Reid Trombetti and R. A. Fielding. 2016. Ageassociated declines in muscle mass, strength, power, and physical performance: impact on fear of falling and quality of life. PMC Osteoporos Int. 27(2): 463-471. 